Jurnal Indonesia Sosial Teknologi: p-ISSN: 2723 - 6609

e-ISSN : 2745-5254

Vol. 2, No. 2 Februari 2021

\title{
PENGARUH KEPUTUSAN INVESTASI, KEPUTUSAN PENDANAAN, DAN KEBIJAKAN DIVIDEN TERHADAP NILAI PERUSAHAAN PADA PERUSAHAAN REAL ESTATE DI BURSA EFEK INDONESIA
}

\author{
Nur Azizah Rasudu dan Susi Sudaryanti \\ Universitas Muhammadiyah Kendari \\ Email: nurazizahrasudu@gmail.com, susysudaryanti20@gmail.com.
}

\section{Abstract}

This study aims to examine the effect of investment decisions as measured by the Investment Opportunity Set (IOS), Funding Decisions as measured by the Debt To Equity Ratio (DER) and Dividend Policy as measured by the Divident Payout Ratio (DPR) on Firm Value as measured by Price Earning. Ratio (PER) in Real Estate Companies on the Indonesia Stock Exchange 2015-2017. The samples in this study were 11 companies with purposive sampling method. Data analysis techniques used Classical Assumption Test and Hypothesis Testing using Multiple Linear Regression Analysis using SPSS 25.0. Based on the results of the research, it shows that partially the investment decision proxied by the Investment Opportunity Set (IOS) and the Dividend Policy proxied by the Divident Payout Ratio (DPR) do not have a significant effect on Firm Value (PER), while the funding decision is proxied by Debt To Equity. The ratio (DER) has a significant effect on Firm Value (PER).

Keyword: investment decision (ios), financing decision (DER), dividend policy (DPR), company value (PER).

\footnotetext{
Abstrak

Penelitian ini bertujuan untuk menguji pengaruh keputusan investasi yang diukur dengan Investment Opportunity Set (IOS), Keputusan Pendanaan yang diukur dengan Debt To Equity Rasio (DER) dan Kebijakan Dividen yang diukur dengan Divident Payout Ratio (DPR) terhadap Nilai Perusahaan yang diukur dengan Price Earning Ratio (PER) pada Perusahaan Real Estate di Bursa Efek Indonesia tahun 2015-2017. Sampel dalam penelitian ini sejumlah 11 perusahaan dengan metode Purposive Sampling. Teknik analisis data menggunakan Uji Asumsi Klasik dan Pengujian Hipotesis menggunakan Analisis Regresi Linear Berganda dengan menggunakan SPSS 25.0. Berdasarkan hasil penelitian menunjukkan bahwa secara parsial Keputusan Investasi yang di proxyconn dengan Investment Opportunity Set (IOS) dan Kebijakan Dividen yang di proxyconn Divident Payout Ratio (DPR) tidak mempunyai pengaruh signifikan terhadap Nilai Perusahaan (PER), sedangkan keputusan pendanaan yang di proxykan dengan Debt To Equity Rasio (DER) mempunyai pengaruh signifikan terhadap Nilai Perusahaan (PER).
} 
Kata kunci: keputusan investasi (IOS), keputusan pendanaan (DER), kebijakan dividen (DPR), nilai perusahaan (PER).

\section{Pendahuluan}

Pada umumnya semua perusahaan memiliki tujuan yaitu tujuan jangka pendek dan tujuan jangka panjang. Tujuan jangka pendek perusahaan adalah memperoleh laba, sedangkan dalam jangka panjang, tujuan perusahaan adalah mengoptimalkan nilai perusahaan. Semakin tinggi nilai perusahaan semakin sejahtera pula pemiliknya. Nilai perusahaan akan tercermin dari harga sahamnya (Wahyudi \& Pawestri, 2006). Untuk mengestimasi harga saham pada masa yang akan datang biasanya digunakan pendekatan Price Earning Ratio (nilai perusahaan).

Keputusan investasi merupakan salah satu faktor yang mempengaruhi nilai perusahaan. Keputusan investasi menyangkut keputusan tentang mengalokasikan dana, baik dilihat dari sumber dana (yang berasal dari dalam dan dari luar perusahaan) maupun penggunaan dana untuk tujuan jangka pendek dan jangka panjang. Tujuan dilakukannya keputusan investasi adalah mendapatkan laba yang besar dengan risiko yang dapat dikelola dengan harapan dapat mengoptimalkan nilai perusahaan, yang berarti menaikkan kemakmuran pemegang saham (Sartini \& Purbawangsa, 2014).

IOS merupakan keputusan investasi dalam bentuk kombinasi aktiva yang dimiliki (assets in place) yang dinilai secara independen dari kesempatan investasi perusahaan di masa yang akan datang dan pilihan pertumbuhan serta opsi investasi di masa yang akan datang, dimana IOS tersebut mempengaruhi nilai suatu perusahaan (value of firm). Artinya semakin tinggi nilai IOS mengindikasikan bahwa apresiasi investor atas kinerja perusahaan dan akan meningkatkan nilai PER (Pagalung, 2003).

Penelitian mengenai keputusan investasi dengan PER yang dilakukan oleh (Zahra, 2017) menemukan bahwa keputusan investasi berpengaruh positif signifikan terhadap PER. Sementara (Bernadi, 2007) menemukan bahwa keputusan investasi tidak berpengaruh terhadap PER.

Keputusan pendanaan didefinisikan sebagai keputusan yang menyangkut komposisi pendanaan yang dipilih oleh perusahaan (Darminto, 2010). Menyatakan, keputusan pendanaan berkaitan dengan proses pemilihan sumber dana yang dipakai untuk membelanjai investasi yang direncanakan dengan berbagai alternatif sumber dana yang tersedia, sehingga diperoleh suatu kombinasi pembelanjaan yang paling efektif (Akbar, 2017). Alternatif pendanaan yang dilakukan oleh perusahaan dapat berasal dari pendanaan internal dan pendanaan eksternal. Pendanaan internal dapat berupa laba ditahan sedangkan pendanaan eksternal dapat berupa hutang, ekuitas dan hybrid securuties.

Kebijakan dividen yaitu menentukan seberapa besar atau proporsi laba yang akan dibagikan sebagai dividen (Anindhita \& MAHFUD, 2010). Kebijikan dividen diproksikan memakai Dividend Payout Ratio (DPR). Kebijakan terhadap pembayaran dividen merupakan keputusan yang sangat penting dalam suatu perusahaan. Kebijakan 252

Jurnal Indonesia Sosial Teknologi, Vol. 2, No. 2, Februari 2021 
Pengaruh Keputusan Investasi, Keputusan Pendanaan, dan Kebijakan Dividen Terhadap Nilai Perusahaan Pada Perusahaan Real Estate di Bursa Efek Indonesia

ini akan melibatkan dua pihak yang mempunyai kepentingan yang berbeda, yaitu pihak pertama para pemegang saham dan pihak kedua perusahaan itu sendiri.

Prospek sektor Real Estate yang bagus dapat ditinjau dari semakin meningkatnya permintaan dan penawaran akan tempat tinggal akibat pertambahan penduduk Indonesia sehingga sangat cocok dijadikan investasi jangka panjang. Berikut adalah gambaran PER, IOS, DER dan DPR yang secara rata-rata dimiliki perusahaan Real Estate.

Tabel 1. Perkembangan dan Rata-rata Investment Opportunity Set, Debt To Equity Ratio, Divident Payout Ratio dan Price Earning Ratio pada Perusahaan Real Estate Tahun 2015-2017

\begin{tabular}{|c|c|c|c|c|c|c|c|c|}
\hline \multirow[b]{2}{*}{ Tahun } & \multirow{2}{*}{\begin{tabular}{l}
\multicolumn{1}{c}{ PER } \\
Million \\
Rp)
\end{tabular}} & \multirow[b]{2}{*}{ Growth } & \multirow{2}{*}{$\begin{array}{c}\text { IOS } \\
\text { (Million } \\
\text { Rp) }\end{array}$} & \multirow[b]{2}{*}{ Growth } & \multirow{2}{*}{$\begin{array}{c}\text { DER } \\
\text { (Million } \\
\text { Rp) }\end{array}$} & \multirow[b]{2}{*}{ Growth } & \multirow{2}{*}{$\begin{array}{c}\text { DPR } \\
\text { (Million } \\
\text { Rp) }\end{array}$} & \multirow[b]{2}{*}{ Growth } \\
\hline & & & & & & & & \\
\hline 2015 & 185.39 & & 53.41 & & 10.32 & & 285.27 & \\
\hline 2016 & 454.71 & 1.45 & 46.4 & -0.13 & 10.59 & 0.02 & 284.62 & -0.002 \\
\hline 2017 & 226.19 & -0.45 & 35.32 & -0.16 & 9.05 & -0.14 & 288.5 & 0.01 \\
\hline $\begin{array}{l}\text { Rata- } \\
\text { Rata }\end{array}$ & 288.76 & 0.5 & 45.04 & -0.15 & 9.98 & -0.06 & 286.13 & 0.004 \\
\hline
\end{tabular}

Sumber: Data Sekunder yang diolah (ICMD \& IDX 2017)

Berdasarkan data tersebut, IOS (Investment Opportunity Set) pada tahun 2016 mengalami penurunan Growth sebesar - 0,13 \% sedangkan pada tahun 2017 Growth IOS mengalami penurunan lagi sebesar $-0,16 \%$, dalam kurun waktu dari tahun ketahun dengan secara rata-rata sebesar -0,15\%. DER (Debt To Equity Ratio) pada tahun 2016 mengalami peningkatan Growth sebesar 0,02\% dan penurunan growth pada tahun 2017 sebesar $-0,14 \%$ dengan secara rata-rata $-0,06 \%$. Sementara DPR (Devident Payout Ratio) pada tahun 2016 mengalami penurunan dengan sebesar $-0.002 \%$ serta kenaikan Growth pada tahun 2017 sebesar 0,01 \% dengan secara rata-rata sebesar 0,004\%. sedangkan PER (Price Earning Ratio) pada tahun 2016 mengalami kenaikan dengan tingkat Growth sebesar 1,45 \% dan pada tahun 2017 PER mengalami penurunan dengan tingkat Growth sebesar - 0,45 \% dengan secara rata-rata sebesar 0,05\%. Dari penjelasan diatas dapat dilihat bahwa terjadi ketidak sesuaian antara teori dan fenomena data yang diperlihatkan pada objek penelitian.

Optimalisasi nilai perusahaan merupakan tujuan utama dari perusahaan (Wahyudi \& Pawestri, 2006). Nilai perusahaan sangat penting karena mencerminkan seberapa besar perusahaan tersebut dapat memberikan keuntungan bagi investor. Untuk dapat memaksimalkan nilai perusahaan tersebut maka manajer dihadapkan pada keputusan keuangan yang meliputi keputusan investasi, keputusan pendanaan dan keputusan yang menyangkut pembagian laba.

Mengingat akan arti penting investasi sebelum mengambil keputusan baik bagi perusahaan maupun investor, dimana perusahaan berkepentingan untuk menjaga kelangsungan perusahaan. Dari berbagai ratio keuangan yang ada salah satu banyak Jurnal Indonesia Sosial Teknologi, Vol. 2, No. 2, Februari 2021 
digunakan dalam mengambil keputusan investasi adalah ratio harga saham terhadap laba bersih saham. Bagi perusahaan untuk membandingkan utang dan ekuitas dalam pendanaan perusahaan menggunakan ratio yang menunjukkan perbandingan antara total hutang dan total ekuitas perusahaan yang digunakan sebagai pendanaan usaha. Sedangkan bagi perusahaan untuk membandingkan dividen yang diberikan dan laba bersih menggunakan ratio yang menunjukkan perbandingan antara dividen yang diberikan pemegang saham dan laba bersih persaham sebagai dividen perusahan.

Penelitian ini hanya difokuskan pada pengaruh beberapa ratio keuangan yaitu Keputusan Investasi yang diproksikan dengan Investment Opportunity Set (IOS), Keputusan Pendanaan yang diproksikan dengan Debt to Equity Ratio (DER) dan Kebijakan Dividen yang diproksikan dengan Dividend Payout Ratio (DPR) terhadap Nilai Perusahaan yang diproksikan dengan Price Earning Ratio (PER) pada perusahaan Real Estate yang terdaftar di Bursa Efek Indonesia tahun 2015-2017.

Menurut (Wahyudi \& Pawestri, 2006), nilai perusahaan yang dibentuk melalui indikator nilai pasar saham sangat dipengaruhi oleh peluang-peluang investasi. Nilai perusahaan semata-mata ditentukan oleh keputusan investasi. Memperkenalkan IOS pada studi yang dilakukan dalam hubungannya dengan keputusan investasi. IOS memberikan petunjuk yang lebih luas dengan nilai perusahaan tergantung pada pengeluaran perusahaan di masa yang akan datang, sehingga prospek perusahaan dapat ditaksir dari Investment Opportunity Set (IOS). IOS didefinisikan sebagai kombinasi antara aktiva yang dimiliki (assets in place) dan pilihan investasi di masa yang akan datang dengan net present value.

Teori yang mendasari keputusan investasi adalah signalling theory. Menurut Jogiyanto (2013:392), signalling theory menekankan kepada pentingnya informasi yang dikeluarkan oleh perusahaan terhadap keputusan investasi pihak di luar perusahaan. Informasi yang dipublikasikan sebagai suatu pengumuman akan memberikan signal bagi investor dalam pengambilan keputusan investasi. Pada saat informasi diumumkan dan pelaku pasar sudah menerima informasi tersebut, pelaku pasar terlebih dahulu mengiterprestasikan dan menganalisa informasi tersebut sebagai sinyal baik ataupun sinyal buruk. Jika pengumuman yang diumumkan sebagai sinyal baik bagi investor maka akan terjadi perubahan volume dalam perdagangan saham.

Sumber pendanaan dapat berasal dari internal perusahaan maupun dari eksternal perusahaan. Menurut (Hasnawati, 2005), proporsi penggunaan sumber dana internal atau eksternal dalam memenuhi kebutuhan dana perusahaan menjadi sangat penting dalam manajemen keuangan perusahaan. Bauran yang optimal akan menyumbangkan benefit dan cost, sehingga akan meminimalkan biaya modal (Darminto, 2010). Dengan demikian, hal ini yang menjadi bahan pertimbangan, karena dengan keputusan pendanaan yang baik dan benar, maka akan menghasilkan nilai yang baik juga.

Keputusan pendanaan terhadap PER menunjukkan hasil yang berbeda, (Rahma \& Djazuli, 2014) menemukan bahwa keputusan pendanaan memiliki pengaruh negatif 
Pengaruh Keputusan Investasi, Keputusan Pendanaan, dan Kebijakan Dividen Terhadap Nilai Perusahaan Pada Perusahaan Real Estate di Bursa Efek Indonesia

terhadap PER, (Pitaloka, 2017) yang meneliti bahwa keputusan pendanaan memiliki pengaruh positif terhadap PER, menemukan bahwa keputusan pendanaan tidak memiliki pengaruh terhadap PER.

Kebijakan dividen (dividend policy) merupakan keputusan seberapa besar laba yang diperoleh perusahaan pada akhir tahun akan dibagi kepada pemegang saham sebagai dividen kas atau disimpan dalam bentuk laba ditahan sebagai sumber pendanaan perusahaan (Ramdhani \& Setyanusa, 2013). Rasio pembayaran dividen (divident payout ratio) akan menunjukkan persentase laba perusahaan yang dibagi kepada pemegang saham biasa dalam bentuk dividen kas. Dalam menemukan bahwa investasi yang dihasilkan dari kebijakan dividen memiliki informasi yang positif tentang perusahaan dimasa yang akan datang, selanjutnya berdampak positif.

(Sartini \& Purbawangsa, 2014) menemukan bahwa DPR berpengaruh negatif, menemukan DPR berpengaruh positif terhadap PER. Sementara (Pratiwi \& Mertha, 2017), (Rahma \& Djazuli, 2014), Menemukan bahwa DPR tidak berpengaruh terhadap PER.

\section{Metode Penelitian}

Objek Penelitian

Obyek dalam penelitian ini dilakukan pada perusahaan Real Estate yang terdaftar di Bursa Efek Indonesiaa pada periode 2015 - 2017.

\section{Populasi Dan Sampel}

Populasi yang digunakan dalam perusahaan ini adalah seluruh perusahaan Real Estate pada Bursa Efek Indonesia (BEI) dari tahun 2015 - 2017 yang memiliki financial statement yang lengkap dan dipublikasikan dalam www.idx.co.id berdasarkan Indonesia Capital Market Directory 2019, yaitu berjumlah 54 perusahaan.

Sampel dalam penelitian ini adalah perusahaan Real Estate yang terdaftar di Bursa Efek Indonesia (BEI) Pada periode 2015 - 2017 yaitu sebanyak 11 perusahaan. sampel perusahaan ini menggunakan teknik purpose sampling yaitu teknik penarikan sampel dengan cara sengaja dengan tujuan tertentu (Sugiyono \& Kuantitatif, 20016). Adapun kriteria sampel yang digunakan dalam penelitian adalah :

1. Perusahaan go publik yang termasuk dalam kelompok Real Estate yang terdaftar di Bursa Efek Indonesia selama periode 2015 - 2017

2. perusahaan sampel menerbitkan laporan keuangan selama periode 2015 2017

3. Perusahaan sampel yang selama periode 2015 - 2017 memiliki PER yang bernilai positif

4. Membayar dividen selama periode 2015 - 2017 . 


\section{Jenis Dan Sumber Data}

Jenis data yang digunakan dalam penelitian ini adalah data kuantitatif yaitu data yang berupa angka-angka yang diperoleh dari laporan perusahan yang telah diaudit melalui Bursa Efek Indonesia dengan www.idx.co.id.

Penelitian ini bersumber dari data sekunder dimana data tersebur adalah data yang berasal dari laporan keuangan perusahaan yang dipublikasikan di Bursa Efek Indonesia khususnya dari website $\underline{w w w . i d x . c o . i d}$.

\section{Metode Pengumpilan Data}

Dalam penelitian ini pengumpulan data dilakukan dengan cara dokumentasi yaitu dengan mengumpulkan data yang meliputi laporan keuangan pada perusahaan Real Estate yang dipulikasikan di Bursa Efek Indonesia tahun 2015- 2017 dari website www.idx.co.id.

\section{Metode Analisa Data}

Metode analisis yang digunakan dalam penelitian ini menggunakan analisis regresi linear berganda dan pengujian hipotesis atau uji $t$.

\section{Metode Pengolahan Data}

Pengelolaan data dalam penelitian ini menggunakan Software SPSS Versi 25.0 sebagai alat untuk regresi modal formulasi. Dalam penelitian ini menggunakan pengujian asumsi klasik yaitu uji normalitas data, heterokedastisitas dan autokorelasi dan pengujian hipotesis.

\section{Analisis Regresi Linear Berganda}

Dalam analisis regresi, selain mengukur kekuatan hubungan antara dua variabel atau lebih, juga menunjukkan arah hubungan antara variabel dependen dengan variabel independen (Watung \& Ilat, 2016). Analisis regresi linier berganda adalah suatu prosedur statistik untuk mengestimasi satu atau lebih variabel independen $(\mathrm{X})$ terhadap variabel dependen (Y). Adapun rumus multiple regresinya adalah sebagai berikut:

Dimana:

$$
Y=a+b_{1} x_{1}+b_{n} x_{n}+e
$$

Y: variabel dependen

$\mathrm{X}$ : variabel independen

a: Konstanta

e: kesalahan pengganggu 
Pengaruh Keputusan Investasi, Keputusan Pendanaan, dan Kebijakan Dividen Terhadap Nilai Perusahaan Pada Perusahaan Real Estate di Bursa Efek Indonesia

Yang kemudian dalam penelitian ini diformulasikan dengan persamaan regresi sebagai berikut :

$$
\mathbf{Y}=\mathbf{a}+\mathbf{b}_{1} \mathbf{x}_{1}+\mathbf{b}_{2} \mathbf{x}_{2}+\mathbf{b}_{3} \mathbf{x}_{3}+\mathbf{e}_{i}
$$

Y

Dimana:

Y : Price Earning Ratio (PER)

$\mathrm{X}_{1} \quad:$ Investment Opportunity Set (IOS)

$\mathrm{X}_{2} \quad$ : Debt To Equity Ratio (DER)

$\mathrm{X}_{3} \quad$ : Divident Payout Ratio (DPR)

a : PER yang tidak dipengaruhi IOS,DER,DPR.

$\mathrm{b}_{1}, \mathrm{~b}_{2}, \mathrm{~b}_{3} \quad$ : koefisien Regresi

$\mathrm{e}_{\mathrm{i}} \quad$ : kesalahan pengganggu

\section{Hasil dan Pembahasan}

\section{Deskriptif Statistik Variabel Penelitian}

Dalam penelitian ini, terdapat empat variable yang akan dianalisis, yang dikelompokkan menjadi dua bagian yaitu variable dependen adalah Nilai perusahaan (PER), sedangkan varabel independen yaitu Keputusan Investasi (IOS), Keputusan Pendanaan (DER) dan Kebijakan Dividen (DPR).

Tabel 2. Deskriptif Statistik

\begin{tabular}{lrrrrrrr}
\hline & N & Minimum & Maximum & Sum & Mean & $\begin{array}{c}\text { Std. } \\
\text { Deviation }\end{array}$ & Variance \\
\hline DER & 33 & 0.24 & 1.40 & 30.27 & 0.9174 & 0.26131 & 0.068 \\
\hline IOS & 33 & 0.89 & 8.77 & 66.96 & 2.0292 & 1.54357 & 2.383 \\
\hline DPR & 33 & 1.54 & 9.77 & 150.01 & 4.5458 & 2.34829 & 5.514 \\
\hline PER & 33 & 2.23 & 15.77 & 151.70 & 4.5970 & 2.48775 & 6.189 \\
\hline $\begin{array}{l}\text { Valid N } \\
\text { (listwise) }\end{array}$ & 33 & & & & & & \\
\hline
\end{tabular}

Sumber : Data Sekunder diolah SPSS 25.0

Berdasarkan output SPSS di atas, maka diperoleh hasil sebagai berikut:

\section{A. Nilai Perusahaan}

Nilai perusahaan ditunjukkan oleh proksi PER. Berdasarkan tabel 2. Statistik deskriptif, besarnya nilai perusahaan pada 11 perusahaan sampel mempunyai nilai ratarata $4.59 \%$ pada standar deviasi $2.48 \%$. Nilai rata-rata (mean) lebih besar dari standar deviasi yaitu $4.59 \%>2.48 \%$, kondisi ini menunjukkan adanya fluktuasi nilai $P E R$ yang kecil pada Perusahaan Real Estate yang menjadi sampel. Sedangkan nilai minimum $2.23 \%$ dan nilai maksimum $15.77 \%$. 


\section{B. Keputusan Investasi}

Keputusan investasi ditunjukkan dengan proksi IOS. Berdasarkan tabel 2. Statistik deskriptif, besarnya IOS pada 11 perusahaan sampel mempunyai nilai rata-rata $2.02 \%$ pada standar deviasi $1.54 \%$. Nilai rata-rata (mean) lebih besar dari standar deviasi yaitu $2.02 \%>1.54 \%$, hal ini menunjukkan adanya fluktuasi nilai IOS yang kecil pada Perusahaan Real Estate yang menjadi sampel. Sedangkan nilai minimum $0.89 \%$ dan nilai maksimum $8.77 \%$.

\section{Keputusan Pendanaan}

Keputusan pendanaan ditunjukkan dengan proksi DER. Berdasarkan tabel 2. Statistik deskriptif, besarnya $D E R$ pada 11 perusahaan sampel mempunyai nilai rata-rata $0.91 \%$ pada standar deviasi $0.26 \%$. Nilai rata-rata (mean) lebih besar dari standar deviasi yaitu $0.91 \%>0.26 \%$, hal ini menunjukkan adanya fluktuasi nilai $D E R$ yang kecil pada Perusahaan Real Estate yang menjadi sampel. Sedangkan nilai minimum $0.24 \%$ dan nilai maksimum $1.40 \%$

\section{Kebijakan Dividen}

Kebijakan dividen ditunjukkan dengan proksi DPR. Berdasarkan tabel 2 . Statistik deskriptif, besarnya $D P R$ pada 11 perusahaan sampel mempunyai rata-rata $4.54 \%$ pada standar deviasi $2.34 \%$. Nilai rata-rata (mean) lebih besar dari standar deviasi yaitu $4.54 \%>2.34 \%$, hal ini menunjukkan adanya fluktuasi nilai $D P R$ yang kecil pada Perusahaan Real Estate yang menjadi sampel. Sedangkan nilai minimum $1.54 \%$ dan nilai maksimum $9.77 \%$.

\section{Hasil Pengujian Asumsi Klasik}

Uji Normalitas Data

Uji normalitas digunakan untuk menguji apakah data sebuah model regresi, variabel independen atau variabel dependen atau keduanya terdistribusi normal atau tidak. Uji normalitas data pada penelitian ini dilakukan dengan Uji Kolmogrof-Smirnov. Berikut hasil pengujian dengan pendekatan Kolmogrow-Smirnov

Tabel 3. One Normalitas (One-Sample Kolmogorov-Smirnov Test )

Unstandardized

Residual

\begin{tabular}{llr}
\hline $\mathrm{N}$ & & 33 \\
\hline Normal & Mean & 0.0000000 \\
\cline { 2 - 3 } Parameters & Std. & 2.14981692 \\
& Deviation & \\
\hline Most Extreme & Absolute & 0.149 \\
\cline { 2 - 3 } Differences & Positive & 0.149
\end{tabular}


Pengaruh Keputusan Investasi, Keputusan Pendanaan, dan Kebijakan Dividen Terhadap Nilai Perusahaan Pada Perusahaan Real Estate di Bursa Efek Indonesia

\begin{tabular}{lr}
\multicolumn{1}{c}{ Negative } & -0.126 \\
\hline Test Statistic & 0.149 \\
\hline Asymp. Sig. (2-tailed) & $.062^{\mathrm{c}}$ \\
\hline a. Test distribution is Normal. & \\
\hline b. Calculated from data. & \\
\hline c. Lilliefors Significance Correction. &
\end{tabular}

Berdasarkan hasil uji diatas nilai signifikan dari uji normalitas sebesar 0.062 yang dimana lebih besar dari nilai signifikansi 0.05. Dari hasil tersebut dapat disimpulkan bahwa data dari variabel penelitian sudah terdistribusi normal.

\section{Uji Heterokedastisitas}

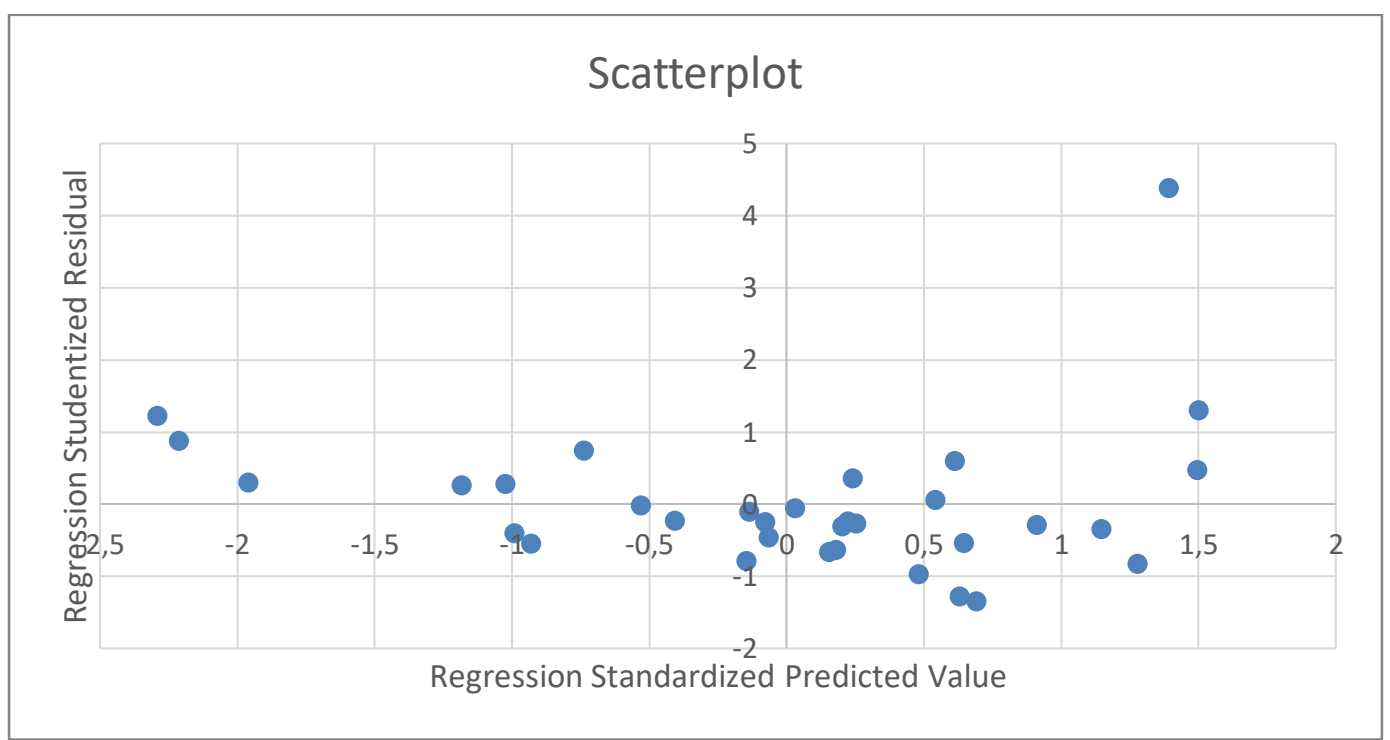

Gambar 2. Pola Gambar Uji Heterokedastisitas scatterplot

Berdasarkan gambar diatas dapat disimpulkan bahwa penelitian ini bebas dari asumsi heteroskedastisitas dikarenakan titik-titik data tidak berpola dan menyebar diatas dan dibawah angka 0 .

Uji Autokorelasi

Tabel 4. Uji Autokorelasi

Model Summary ${ }^{b}$

\begin{tabular}{lrrrrr}
\hline Model & R & R Square & $\begin{array}{c}\text { Adjusted R } \\
\text { Square }\end{array}$ & $\begin{array}{c}\text { Std. Error } \\
\text { of the } \\
\text { Estimate }\end{array}$ & $\begin{array}{c}\text { Durbin- } \\
\text { Watson }\end{array}$ \\
\hline 1 & $.503^{\mathrm{a}}$ & 0.253 & 0.176 & 2.25828 & 1.595
\end{tabular}

a. Predictors: (Constant), DPR, IOS, DER

b. Dependent Variable: PER

Sumber: Lampiran 2

Jurnal Indonesia Sosial Teknologi, Vol. 2, No. 2, Februari 2021 
Berdasarkan hasil tabel uji autokorelasi diketahui DW $=1.595$. Berdasarkan nilai uji statistik Durbin-Watson dalam penelitian berada diatas satu dan dibawah tiga sehingga tidak terjadi autokorelasi.

\section{Analisis Regresi Linear Berganda}

Analisis regresi linier berganda digunakan untuk mengetahui pengaruh profitabilitas, keputusan investasi, keputusan pendanaan, dan kebijakan dividen terhadap nilai perusahaan. Analisis ini diolah dengan bantuan program SPSS. Hasil analisis regresi linier berganda dapat dilihat pada tabel di bawah ini:

Tabel 5. Hasil Regresi Linear Berganda

Coefficients $^{\mathrm{a}}$

\begin{tabular}{|c|c|c|c|c|c|c|c|c|}
\hline \multirow{2}{*}{\multicolumn{2}{|c|}{ Model }} & \multicolumn{2}{|c|}{$\begin{array}{c}\text { Unstandardized } \\
\text { Coefficients }\end{array}$} & \multirow{2}{*}{$\begin{array}{c}\text { Standardized } \\
\text { Coefficients } \\
\text { Beta } \\
\end{array}$} & \multirow[b]{2}{*}{$\mathrm{t}$} & \multirow[b]{2}{*}{ Sig. } & \multicolumn{2}{|c|}{$\begin{array}{c}\text { Collinearity } \\
\text { Statistics }\end{array}$} \\
\hline & & $\mathrm{B}$ & $\begin{array}{l}\text { Std. } \\
\text { Error }\end{array}$ & & & & Tolerance & VIF \\
\hline \multirow[t]{4}{*}{1} & (Constant) & -1.088 & 2.616 & & -0.416 & 0.680 & & \\
\hline & IOS & -0.164 & 0.259 & -0.101 & -0.631 & 0.533 & 0.995 & 1.005 \\
\hline & DER & 5.615 & 1.975 & 0.590 & 2.843 & 0.008 & 0.598 & 1.672 \\
\hline & DPR & 0.190 & 0.220 & 0.180 & 0.866 & 0.394 & 0.597 & 1.675 \\
\hline
\end{tabular}

a. Dependent Variable: PER

Hasil regresi linier berganda dapat dimasukkan dalam persamaan menjadi:

$\mathbf{Y}=\mathbf{a}+\mathbf{b}_{1} \mathbf{X}_{1}+\mathbf{b}_{2} \mathbf{X}_{2}+\mathbf{b}_{3} \mathbf{X}_{3}+\mathbf{e}_{\mathbf{i}}$

$\mathbf{Y}=-1.088-0.164+5.615+0.190$

Persamaan regresi diatas menjelaskan nilai konstan sebesar $-1.088 \%$, ini berarti bahwa $P E R$ akan tetap sebesar $-1.088 \%$. IOS mempunyai koefisien regresi -0.164 memiliki arah yang negatif terhadap PER. Hal ini berarti bahwa setiap penurunan IOS sebesar $1 \%$ akan menyebabkan penurunan terhadap PER sebesar $-0.164 \%$ dengan asumsi variable lain tetap.

Koefisien regresi $D E R$ sebesar 5.615 dengan memiliki arah positif terhadap $P E R$. Hal ini berarti bahwa setiap kenaikan DER sebesar 1\% akan menyebabkan kenaikan terhadap PER sebesar 5.615\% dengan asumsi variable lain tetap.

Koefisien regresi $D P R$ sebesar 0.190 dengan memiliki arah positif terhadap $P E R$. Hal ini berarti bahwa setiap kenaikan $D P R$ sebesar $1 \%$ akan menyebabkan kenaikan terhadap PER sebesar $0.190 \%$ dengan asumsi variable lain tetap.

\section{Pengujian Hipotesis}

Pengujian melalui uji $\mathrm{t}$ dilakukan dengan membandingkan $\mathrm{t}$ hitung dengan $\mathrm{t}$ tabel atau melihat nilai t sig pada taraf signifikan $(\mathrm{p})=5 \%$, dengan kriteria sebagai berikut :

1. Jika nilai nilai t sig $>0,05$ (taraf kepercayaan $\alpha=5 \%$ ), maka Ho diterima. 
Pengaruh Keputusan Investasi, Keputusan Pendanaan, dan Kebijakan Dividen Terhadap Nilai Perusahaan Pada Perusahaan Real Estate di Bursa Efek Indonesia

2. Jika nilai nilai nilai $\mathrm{t} \operatorname{sig}<0,05$ (taraf kepercayaan $\alpha=5 \%$ ), maka Ho ditolak yang berarti menerima Ha.

Berdasarkan dari kriteria pengujian hipotesis tersebut diatas, maka dapat diuraikan sebagai berikut :

\section{UJi Hipotesis Pertama ( Variabel Investment Opoortunity Set $\left(\mathrm{X}_{1}\right)$ )}

Berdasarkan table 5 diketahui nilai $\mathrm{t}_{\text {hitung }} \leq \mathrm{t}_{\text {tabel }}=-0.631 \leq 2.045$ dengan tingkat signifikansi $0.533 \geq 0.05$. Jadi dapat disimpulkan bahwa Variabel Investment Opoortunity Set tidak memiliki pengaruh terhadap Price Earning Ratio.

\section{UJi Hipotesis Kedua ( Variabel Debt to Equity Ratio $\left(\mathrm{X}_{2}\right)$ )}

Berdasarkan table 5 diketahui nilai $t_{\text {hitung }} \geq t_{\text {tabel }}=2.843 \geq 2.056$ dengan tingkat signifikansi $0.008 \leq 0.05$. Jadi dapat disimpulkan bahwa Variabel Debt to Equity Ratio memiliki pengaruh terhadap Price Earning Ratio.

\section{UJi Hipotesis Ketiga ( Variabel Divident Payout Ratio $\left(\mathrm{X}_{3}\right)$ )}

Berdasarkan table 5 diketahui nilai $\mathrm{t}_{\text {hitung }} \leq \mathrm{t}_{\text {tabel }}=0.866 \leq 2.056$ dengan tingkat signifikansi $0.394 \geq 0.05$. Jadi dapat disimpulkan bahwa Variabel Divident Payout Ratio tidak memiliki pengaruh terhadap Price Earning Ratio.

\section{Pembahasan}

\section{Pengaruh Investment Opportunity Set Terhadap Price Earning Ratio}

Berdasarkan tabel 5 IOS dalam penelitian ini berpengaruh negatif disebabkan karena berdasarkan hasil deskripsi variabel penelitian IOS secara nilai pertumbuhan memiliki nilai -0.09 sementara hasil deskripsi variable PER memiliki nilai 0.33. Hal ini menunjukkan penurunan IOS tidak diikuti dengan penurunan PER.

Berdasarkan hasil Uji t untuk variable IOS $\left(\mathrm{X}_{1}\right)$ diperoleh nilai $\mathrm{t}_{\text {hitung }} \leq \mathrm{t}_{\text {tabel }}=-$ $0.631 \leq 2.056$ dengan tingkat signifikansi $0.533 \geq 0.05$. Maka dengan demikian $\mathrm{H}_{\mathrm{a}}$ ditolak dan $\mathrm{H}_{\mathrm{o}}$ diterima. Hal ini berarti bahwa Variabel Investment Opoortunity Set tidak memiliki pengaruh signifikan terhadap Price Earning Ratio. Jadi dapat disimpulkan bahwa IOS tidak berpengaruh secara negative dan tidak signifikan terhadap PER.

Hasil ini sesuai dengan penelitian Wahyudi, Bernadi dan Muh. Zakin yang menemukan bahwa Investment Opoortunity Set tidak memiliki pengaruh negatif signifikan terhadap Price Earning Ratio.

\section{Pengaruh Variabel Debt to Equity Ratio Terhadap Price Earning Ratio}

Berdasarkan tabel 5 DER dalam penelitian ini berpengaruh negatif disebabkan karena berdasarkan hasil deskripsi variabel penelitian $D E R$ secara nilai pertumbuhan 
memiliki nilai -0.04 sementara hasil deskripsi variable $P E R$ memiliki nilai 0.33 . Hal ini menunjukkan penurunan DER tidak diikuti dengan penurunan PER.

Hasil Uji $\mathrm{t}$ diketahui nilai $\mathrm{t}_{\text {hitung }} \geq \mathrm{t}_{\text {tabel }}=2.843 \geq 2.045$ dengan tingkat signifikansi $0.008 \leq 0.05$. Maka dengan demikian $\mathrm{H}_{\mathrm{a}}$ diterima dan $\mathrm{H}_{\mathrm{o}}$ ditolak. Hal ini berarti bahwa Variabel Debt to Equity Ratio memiliki pengaruh signifikan terhadap Price Earning Ratio. Jadi dapat disimpulkan bahwa DER berpengaruh secara negatif dan signifikan terhadap PER.

Hal ini sesuai dengan Modigliani dan Miller mengemukakan bahwa penambahan hutang akan menaikkan nilai perusahaan. Serta berdasarkan teori trade off yang mengatakan kenaikan hutang akan bermanfaat jika dapat meningkatkan nilai perusahaan artinya bahwa perusahaan belum mencapai titik optimal (suatu batas optimal dari jumlah hutang yang dapat menyebabkan nilai perusahaan maksimal) dan jika manfaat hutang menjadi lebih besar akan semakin besar resiko kebangkrutan karena ketidak mampuan perusahaan membayar hutang makan penambahan hutang akan menurunkan nilai perusahaan.

Hasil ini sesuai dengan penelitian (Rahma \& Djazuli, 2014), dan (Adam, 2015) yang menemukan bahwa Debt to Equity Ratio memiliki pengaruh secara negatif dan signifikan terhadap Price Earning Ratio.

\section{Pengaruh Variabel Divident Payout Ratio Terhadap Price Earning Ratio}

Berdasarkan tabel $5 D P R$ dalam penelitian ini berpengaruh positif disebabkan karena berdasarkan hasil deskripsi variabel penelitian $D P R$ secara nilai pertumbuhan memiliki nilai 0.002. Sementara hasil deskripsi variable $P E R$ memiliki nilai 0.33 . Hal ini menunjukkan kenaikan $D P R$ diikuti dengan kenaikan $P E R$.

Berdasarkan hasil uji $\mathrm{t}$ diketahui bahwa diketahui nilai $\mathrm{t}_{\text {hitung }} \leq \mathrm{t}_{\text {tabel }}=0.866 \leq$ 2.045 dengan tingkat signifikansi $0.394 \geq 0.05$. Maka dengan demikian $\mathrm{H}_{\mathrm{a}}$ ditolak dan $\mathrm{H}_{\mathrm{o}}$ diterima. Jadi dapat diartikan bahwa bahwa Variabel Divident Payout Ratio tidak memiliki pengaruh signifikan terhadap Price Earning Ratio. Jadi dapat disimpulkan bahwa variable $D P R$ tidak berpengaruh secara positif dan tidak signifikan terhadap PER.

Hasil penelitian ini mengindikasikan bahwa kemampuan perusahaan membayar dividen bukan merupakan pertimbangan utama investor dalam membeli saham. Hasil penelitian ini sejalan dengan pendapat yang dikemukakan Modigliani dan Miller bahwa nilai suatu perusahaan tidak ditentukan oleh pembayaran dividen, tetapi oleh Earning Power perusahaan. Modigliani dan Miller menyatakan bahwa, dividend payout ratio (DPR) hanya merupakan bagian kecil dari keputusan pendanaan perusahaan. Dividend Payout Ratio tidak mempengaruhi kekayaan pemegang saham. Modigliani dan Miller beragumentasi bahwa nilai perusahaan ditentukan tersendiri oleh kemampuan aktiva perusahaan untuk menghasilkan laba. Jadi kebijakan perusahaan dalam membagi laba 
Pengaruh Keputusan Investasi, Keputusan Pendanaan, dan Kebijakan Dividen Terhadap Nilai Perusahaan Pada Perusahaan Real Estate di Bursa Efek Indonesia

perusahaan menjadi dividen dan laba yang ditahan tidak mempengaruhi nilai perusahaan.

Hasil penelitian ini sejalan dengan penelitian sebelumnya yang telah dilakukan oleh (Siahaan, 2011), (Sudjiman \& Sudjiman, 2020) dan (Adeviana, 2018) yang menyatakan bahwa Divident Payout Ratio tidak memiliki pengaruh terhadap Price Earning Ratio.

\section{Kesimpulan}

Berdasarkan hasil analisis dan pembahasan tentang pengaruh keputusan investasi dan keputusan pendanaan dan kebijakan dividen terhadap nilai perusahaan pada Perusahaan Real Estate Di Bursa Efek Indonesia menunjukkan bahwa Investment Opportunity Set (IOS) dalam penelitian ini tidak berpengaruh secara negatif dan tidak signifikan terhadap Price Earning Ratio (PER). Pengaruh Debt to Equity Ratio (DER) dalam penelitian ini berpengaruh negatif signifikan terhadap Price Earning Ratio (PER). Pengaruh Divident Payout Ratio (DPR) dalam penelitian ini tidak berpengaruh secara positif dan signifikan terhadap Price Earning Ratio (PER). Hasil penelitian ini mengindikasikan bahwa kemampuan perusahaan membayar dividen bukan merupakan pertimbangan utama investor dalam membeli saham. . Jadi kebijakan perusahaan dalam membagi laba perusahaan menjadi dividen dan laba yang ditahan tidak mempengaruhi nilai perusahaan. 


\section{Bibliography}

Adam, Echan. (2015). Variabel-Variabel yang Mempengaruhi Rasio P/E dan Dampaknya terhadap Return Saham (Studi pada Perusahaan Manufaktur yang Terdaftar di Bursa Efek Indonesia). Jurnal Aplikasi Manajemen, 13(4), 714-728.

Adeviana, Adeviana. (2018). Pengaruh Dividend Payout Ratio, Debt To Equity Ratio, Current Ratio, Net Profit Margin, Total Asset Turnover Dan Firm Size Terhadap Price Earning Ratio Pada Perusahaan Yang Terdaftar Di Indeks Lq 45 Bursa Efek Indonesia Tahun 2016. Universitas Widya Dharma.

Akbar, Rizki Rifaldi. (2017). Analisis Model Indeks Tunggal Dan Teknik Fundamental Dalam Menentukan Keputusan Investasi Pada Perusahaan Indeks Kompas100 Yang Terdaftar Di Bursa Efek Indonesia Tahun 2014-2015. Universitas Widyatama.

Anindhita, Galih, \& MAHFUD, Kholiq. (2010). Analisis Reaksi Pasar atas Pengumuman Dividen Sebelum dan Sesudah Ex-Dividend Date (Studi Kasus pada Kelompok Cash Dividend Final Naik dan Turun Pada Perusahaan-Perusahaan yang Terdaftar di BEJ Tahun 2004-2006). Universitas Diponegoro.

Bernadi, K. Jemmi. (2007). Analisis Pengaruh Cashflow dan Kebijakan Pecking Order Terhadap Leverage dan Investasi serta Dampaknya Terhadap Nilai Perusahaan (Studi Pada Perusahaan-Perusahaan Sektor Manufaktur). Disertasi. Program Pascasarjana Universitas Brawijaya.

Darminto, Darminto. (2010). Pengaruh Faktor Eksternal dan Berbagai Keputusan Keuangan terhadap Nilai Perusahaan. Jurnal Aplikasi Manajemen, 8(1).

Hasnawati, Sri. (2005). Dampak Set Peluang Investasi Terhadap Nilai Perusahaan Publik di Bursa Efek Jakarta. Jurnal Akuntansi dan Auditing Indonesia, 9(2).

Pagalung, Gagaring. (2003). Pengaruh Kombinasi Keunggulan dan Keterbatasan Perusahaan Terhadap Set Kesempatan Investasi (IOS). The Indonesian Journal of Accounting Research, 6(3).

Pitaloka, Endang. (2017). Pengaruh Return on Equity, Earning per Share (EPS), dan Debt to Equity Ratio terhadap Price Earning Ratio (PER) Pada PT Indofood Sukses Makmur. Tbk Periode 2012-2014. Widyakala: Journal Of Pembangunan Jaya University, 4(1), 52-59.

Pratiwi, Ni Putu Diah, \& Mertha, Made. (2017). Pengaruh Kebijakan Hutang dan Profitabilitas Pada Nilai Perusahaan dengan Kebijakan Dividen Sebagai Variabel Pemoderasi. E-Jurnal Akuntansi, 20(2), 1446-1475.

Rahma, Erlin Yulia, \& Djazuli, Atim. (2014). Analisis Variabel Fundamental yang 264 Jurnal Indonesia Sosial Teknologi, Vol. 2, No. 2, Februari 2021 
Pengaruh Keputusan Investasi, Keputusan Pendanaan, dan Kebijakan Dividen Terhadap Nilai Perusahaan Pada Perusahaan Real Estate di Bursa Efek Indonesia

Berpengaruh Terhadap Price Earning Ratio (PER) Sebagai Dasar Penilaian Saham Pada Perusahaan Automotive and Allied yang Terdaftar di Bursa Efek Indonesia. Jurnal Aplikasi Manajemen, 12(3), 362-372.

Ramdhani, Gilang, \& Setyanusa, Inta Budi. (2013). Pengaruh Laba Per Lembar Saham (EPS) dan Rasio Pengembalian Modal (ROE) Terhadap Harga Saham (Studi Kasus Pada Perusahaan Sektor Perbankan yang Terdaftar di Bursa Efek Indonesia Periode 2009-2012). ISSN: 2086-0447 Jurnal Riset Akuntansi, Volume V / No.1 / April 2013.

Sartini, Luh Putu Novita, \& Purbawangsa, Ida Bagus Anom. (2014). Pengaruh Keputusan Investasi, Kebijakan Deviden, Serta Keputusan Pendanaan Terhadap Nilai Perusahaan Manufaktur Di Bursa Efek Indonesia. Matrik: Jurnal Manajemen, Strategi Bisnis dan Kewirausahaan.

Siahaan, Fadjar O. P. (2011). Pengaruh Kebijakan Hutang dan Investasi Terhadap Nilai Perusahaan. EL MUHASABA: Jurnal Akuntansi (e-Journal), 2(2).

Sudjiman, Paul Eduard, \& Sudjiman, Lorina Siregar. (2020). Effect Of Roa Towards Price Earning Ratio: A Study On Cosmetic An Household Needs Subsector Companies. Jurnal Ekonomis, 13(1), 39-50.

Sugiyono, M. P. P., \& Kuantitatif, P. (2016). Kualitatif dan R\&D, Bandung: Alfabeta. Cet. VII.

Wahyudi, Untung, \& Pawestri, Hartini Prasetyaning. (2006). Implikasi Struktur Kepemilikan Terhadap Nilai Perusahaan: Dengan Keputusan Keuangan Sebagai Variabel intervening. Simposium Nasional Akuntansi, 9, 1-25.

Watung, Rosdian Widiawati, \& Ilat, Ventje. (2016). Pengaruh Return On Asset (Roa), Net Profit Margin (NPM), dan Earning Per Share (EPS) Terhadap Harga Saham Pada Perusahaan Perbankan Di Bursa Efek Indonesia Periode 2011-2015. Jurnal EMBA: Jurnal Riset Ekonomi, Manajemen, Bisnis Dan Akuntansi, 4(2).

Zahra, Fatimatus. (2017). Pengaruh Corporate Governance, Profitabilitas, dan Capital Intensity Terhadap Penghindaran Pajak. Jakarta: Fakultas Ekonomi dan Bisnis UIN Syarif Hidayatullah Jakarta. 